\title{
PENGAMATAN DI KLINIK SANDJOJO SEHAT BSB: TARGET VS REALITAS PENCAPAIAN
}

\author{
Edward Hartono
}

Fakultas Kedokteran, Universitas Katolik Soegijapranata, Semarang, Indonesia

Korespondensi Penulis:

Nama $\quad$ : dr. Edward Hartono, M.ARS.

Alamat : Jl. Pawiyatan Luhur IV No. 1 Bendan Duwur - Semarang 50234 - Indonesia

Nomor Telepon : 8441555 (hunting)

Email : : edward@unika.ac.id

\begin{abstract}
Abstrak
Di setiap usaha diperlukan panduan untuk pencapaian dan perkembangan dalam hal ini Klinik Sandjojo Sehat juga memiliki panduan untuk perkembangan salah satunya yaitu target jumlah pasien per bulan. Tujuan dari studi ini untuk mengetahui kesesuaian antara target sebagai panduan dengan realitas yang dicapai yaitu jumlah pasien per bulan. Metode yang digunakan adalah menganalisa data jumlah pasien Klinik Sandjojo Sehat dimulai dari bulan Juli 2020 sampai dengan Juni 2021 sebagai dasar untuk perbandingan dengan target yang ditentukan dalam periode pelayanan yang sama. Dari analisa tersebut didapatkan bahwa target jumlah pasien tidak sesuai dengan realitas pencapaian.
\end{abstract}

Kata kunci: target dan realitas pencapaian, jumlah pasien, Klinik Sandjojo.

\begin{abstract}
Every business requires guidelines for achievement and development, in this case the Sandjojo Sehat Clinic also has guidelines for development, namely the target number of patients monthly. The purpose of this study was to determine the suitability of the target as a guide with the reality achieved in the number of patients monthly. The method used is to analyze data on the number of patients of the Sandjojo Sehat Clinic starting from July 2020 to June 2021 as a basis for comparison with the targets specified in the same service period. From this analysis, it was found that the target number of patients was not in accordance with the reality of achievement.
\end{abstract}

Keyword: target and reality of achievement, number of patients, the Sandjojo Sehat Clinic.

\section{Pendahuluan}

Klinik Sandjojo Sehat yang berlokasi di BSB, Mijen merupakan Klinik Pratama yang dioperasionalkan Juli 2020 sebagai pelopor fasilitas kesehatan Tingkat Pertama yang dimiliki Yayasan Sandjojo untuk memberikan pelayanan di wilayah Mijen dan sekitarnya. Adapun klinik ini didirikan dengan tujuan sebagai langkah awal pelayanan sebelum didirikannya fasilitas kesehatan tingkat lanjut yaitu RS Sandjojo yang akan didirikan di wilayah yang sama.

Klinik Sandjojo Sehat selaku usaha bisnis dalam persiapannya juga telah ditentukan beberapa target untuk pencapaian perkembangannya yang dapat dipantau secara berkala sampai 
akhirnya bisa mencapai break event point dan payback period. Adapun target yang ditentukan yang dianalisa saat ini adalah pencapaian jumlah pasien tiap bulannya.

Target pencapaian jumlah pasien bulanan akan dibandingkan dengan realitas pencapaian untuk periode Mei 2020 sampai dengan Juni 2021. Sehingga nantinya dapat dilihat kesesuaian anatar target sebagai panduan dengan realitas pencapaiannya.

\section{Metode}

Dalam studi Pengamatan di Klinik Sandjojo Sehat BSB : Target VS Realitas Pencapaian menggunakan data sekunder dari jumlah pasien bulanan di periode Juli 2020 sampai Juni 2021 yang akan memberikan gambaran kesesuaian antara target dan realitas pencapaian. Penelitian bersifat deskriptif dan jenis nya cross sectional.

\section{Hasil}

\section{Jumlah Pasien}

Target pasien bulanan yang diberikan oleh konsultan adalah 100 pasien per hari dan 28 hari kerja atau 2.800 pasien per bulan. Target yang diberikan ini bersifat flat dan dimulai langsung dari mulai dibukanya klinik di bulan Juli 2020 dan seterusnya sampai tujuh tahun ke depannya. Adapun jumlah pasien ini mencakup pasien dokter umum, dokter gigi, pemeriksaaan kesehatan berkala, pemeriksaan laboratorium sederhana.

Berdasarkan data sekunder yang didapatkan dari Klinik Sandjojo Sehat dari bulan Juli 2020 sampai Juni 2021 yang mencakup seluruh pemeriksaan yang ditargetkan.

Tabel 1. Tabel Jumlah Pasien Periode Juli 2020-Juni 2021

\begin{tabular}{rccc}
\hline \multicolumn{1}{c}{ Bulan } & Pencapaian Pasien per bulan & Pencapaian pasien harian \\
\hline Juli & 2020 & 147 & 5 \\
\hline Agustus & 2020 & 97 & 3 \\
\hline September & 2020 & 53 & 2 \\
\hline Oktober & 2020 & 86 & 3 \\
\hline November & 2020 & 123 & 4 \\
\hline Desember & 2020 & 179 & 6 \\
\hline Januari & 2021 & 452 & 16 \\
\hline Februari & 2021 & 380 & 14 \\
\hline Maret & 2021 & 235 & 12 \\
\hline April & 2021 & 327 &
\end{tabular}




\begin{tabular}{cccc}
\hline Bulan & Pencapaian Pasien per bulan & Pencapaian pasien harian \\
\hline Bulan & & Pencapaian Pasien per bulan & Pencapaian pasien harian \\
\hline Mei & 2021 & 217 & 8 \\
\hline Juni & 2021 & 539 & 19 \\
\hline
\end{tabular}

Tabel 2. Tabel Perbandingan Target dan Pencapaian Jumlah Pasien Periode Juli 2020-Juni 2021

\begin{tabular}{cccc}
\hline \multicolumn{1}{c}{ Bulan } & Target Pasien per bulan & $\begin{array}{c}\text { Pencapaian pasien } \\
\text { bulanan }\end{array}$ \\
\hline Juli & 2020 & 2800 & 147 \\
\hline Agustus & 2020 & 2800 & 97 \\
\hline September & 2020 & 2800 & 53 \\
\hline Oktober & 2020 & 2800 & 86 \\
\hline November & 2020 & 2800 & 123 \\
\hline Desember & 2020 & 2800 & 179 \\
\hline Januari & 2021 & 2800 & 452 \\
\hline Februari & 2021 & 2800 & 380 \\
\hline Maret & 2021 & 2800 & 235 \\
\hline April & 2021 & 2800 & 327 \\
\hline Mei & 2021 & 2800 & 217 \\
\hline Juni & 2021 & 2800 & 539 \\
\hline
\end{tabular}

\section{Pembahasan}

Berdasarkan hasil yang kita kumpulkan dari data sekunder maka kita bahas yaitu kesesuaian target dan realitas pencapaian jumlah pasien bulanan Klinik Sandjojo Sehat periode Juli 2020 - Juni 2021.

\section{Jumlah Pasien}

Hasil yang didapat dari pencapaian jumlah pasien bulanan dari periode Juli 2020 sampai dengan Juni 2021 didapatkan hasil yang jauh dari target yang diberikan yaitu 2.800 pasien per bulan bahkan jika ditotal seluruh pasien dalam satu periode pengamatan hanya mencapai 2.835 pasien yang hanya 35 pasien lebih banyak dari target satu bulanan. Mengapa demikian ? jika ditelaah dari target yang ditentukan maka target harian dari Klinik Sandjojo Sehat adalah seratus(100) pasien untuk delapan (8) jam pelayanan. Maka didapatkan dalam satu jam pelayanan harus dapat melayani sekitar dua belas setengah(12.5) pasien. Padahal kenyataannya di satu periode pengamatan pencapaiannya bersifat fluktuatif. Di bulan Juli pencapaian rata-rata harian adalah sebanyak lima(5) pasien. Sampai dengan bulan Desember 2020 rata-rata harian juga naik turun tidak jauh dari pencapaian di bulan Juli 2020. Sedangkan pencapaian di tahun 2021 sudah 
dapat menjadi dua digit yaitu antara duabelas(12) sampai dengan sembilan belas (19) pasien per hari kecuali di bulan Maret dan Mei yang hanya mencapai delapan pasien per hari. Maka pencapaian tertinggi adalah sembilan belas (19) pasien per delapan jam pelayanan di periode Juni 2021. Menurut panduan pelayanan IDI maka idealnya pasien mendapatkan pelayanan adalah selama lima belas(15) menit per pasien yang mencakup proses anamnesis, pemeriksaan fisik dan diagnosis. Jadi untuk pelayanan dokter umum dalam satu jam sebanyak empat(4) pasien atau tiga puluh dua (32) pasien dalam sehari. Sedangkan untuk pelayanan gigi akan lebih lama lagi yaitu sekitar tiga puluh (30) menit per pasien untuk melakukan ketiga proses yang kurang lebihnya sama dengan kegiatan dokter umum sehingga total enam belas(16) pasien gigi per hari. Idealnya adalah empat puluh delapan(48) pasien di luar pasien laboratorium. Berdasarkan pengalaman empiris penulis maka pemeriksaan laboratorium umumnya sepuluh(10) persen dari total pasien yaitu sekitar lima(5) pasien. Sehingga idealnya target pelayanan harian adalah sekitar lima puluh tiga(53) pasien.

Selain itu Klinik Sandjojo Sehat sebagai suatu usaha bisnis yang baru dimulai butuh waktu untuk dapat memasarkan produk sehingga dikenal oleh masyarakat cakupannya atau ada kondisi tertentu yang dapat mendorong perkembangan secara situasional. Kebutuhan akan waktu dikenalnya oleh masyarakat berbeda-beda namun secara umum selama satu tahun pertama. Sehingga target akan jumlah pasien bulanan tidak dapat ditentukan bulanan jauh lebih ideal ditentukan triwulan atau caturwulan dan tidak bersifat flat atau sama karena setiap waktu akan memberikan hasil yang berbeda. Semakin lama dikenal masyarakat tentunya diasumsikan jumlah pasien akan lebih meningkat sehingga target dapat disesuaikan.

Berdasarkan data yang didapat maka di tahun 2021 pasien yang dilayani memang mengalami peningkatan cukup pesat karena suatu kondisi tertentu yang mendorong perkembangan secara eksponensial meskipun belum mencapai target yang diberikan. Adapun kondisi tersebut adalah kondisi pandemi covid 19. Kondisi ini menyebabkan peningkatan jumlah pemeriksaan laboratorium baik antibodi, antigen maupun pemeriksaan PCR dan juga konsultasi dokter umum yang berhubungan dengan kondisi pasien yang positif dari hasil pemeriksaan laboratorium tersebut.

\section{Kesimpulan dan Saran}


Setelah melakukan pembahasan maka dapat ditarik simpulan bahwa target yang diberikan tidak sesuai dengan pencapaian bahkan pencapaian selama satu(1) tahun periode pelayanan baru dapat melewati target bulanan yang diberikan. Hal ini tidak tercapai karena target bersifat sama rata di tiap bulannya sehingga klinik masih dalam proses perkembangan dan belum mampun mencapai target yang ada. selain itu target yang diberikan jika berdasarkan panduan waktu pelayanan pasien, angka yang diberikan jauh tinggi melebihi estimasi yang ada.

Berdasarkan simpulan diatas maka dapat disarankan beberapa hal sebagai berikut. Pertama, sebuah usaha bisnis dalam hal ini Klinik Sandjojo Sehat membutuhkan periode waktu tertentu untuk dikenal dengan masyarakat sehingga fungsi pelayanan dapat berkembang dan tercermin dalam peningkatan jumlah pasien bulanannya. Kedua, target yang ditentukan tidak dapat serta merta bersifat sama rata dimulai dari pembukaan sampai ke tahun - tahun berikutnya, dibutuhkan target yang bersifat dinamis dan bertahap meningkat sesuai dengan kondisi. Ketiga, pemberian target harus disesuaikan dengan kemungkinan keberhasilan pencapaian bukan hanya target yang tidak mungkin dicapai. Keempat, sebaiknya pembuatan target pasien disesuaikan dengan panduan waktu pelayanan yang ada sehingga berdampak terhadap target yang ada. Kelima, perlunya target dan evaluasi terhadap pencapaian yang bersifat triwulan maupun caturwulan bukan bulanan karena perlu adanya waktu dalam pengembangan suatu usaha. Keenam, diperlukan usaha lebih dalam memasarkan pelayanan baik secara konvensional maupun cara kekininan dengan sosial media.

\section{Daftar Pustaka}

1. Peraturan Menteri Kesehatan Republik Indonesia Nomor 028/Menkes/Per/I/2021 mengenai Klinik

2. Nofriadi, N., Delima, M., \& Sara, Y. (2019). Hubungan Lama Waktu Tunggu Pelayanan Dengan Kepuasan Pasien Poli Penyakit Dalam RSUD Painan. PROSIDING SEMINAR KESEHATAN PERINTIS, 2(1), 67.

3. Analisis Hubungan Waktu Pelayanan dan Faktor Total Quality Service Terhadap Kepuasan Pasien di Poliklinik Kebidanan dan Kandungan RSIA Anugerah Medical Centre Kota Metro Tahun 2015

4. Perbedaan Kualitas Pelayanan Berdasarkan Waktu Tunggu serta Rasio Rujukan Pasien Dokter keluarga Ida Srisurani Wiji Astuti1, Bhisma Murti2, Ari Natalia Probandari3

5. Analisis Waktu Tunggu Rawat Jalan di Rumah Sakit Umum

6. Daerah Dr Achmad Darwis Suliki Tahun 2019 Suspenti Dewi1, Rizanda Machmud2, Yuniar 
Jurnal Pranata Biomedika, Volume 1, No 1, Maret 2022

e-ISSN: 2828-1233

Lestari2 